\title{
Evaluation of phytochemicals and antibacterial activity of leaf and leaf derived callus extracts of Artemisia annua L. and Sauropus androgynus (L.) Merr.
}

\author{
Manasa Govindaraju, Mahendra Chikkamadaiah*, Murali Mahadevamurthy, Mahesh \\ Holenarsipura Mylari and Sudarshana Mysore Shankar Singh
}

Department of Studies in Botany, University of Mysore, Manasagangotri, Mysuru- 570006 (Karnataka), INDIA

${ }^{*}$ Corresponding author. E-mail: mahendra.c149@gmail.com

Received: April 7, 2016; Revised received: September 2, 2016; Accepted: November 23, 2016

\begin{abstract}
The present study focuses on the use of salicylic acid as a plant growth hormone for the induction of callus in Sauropus androgynus and Artemisia annua plants. Higher induction of callus of $72 \%$ in $S$. androgynus (NAA+BAP+SA at $+2.5+2.5 \mathrm{mg} / \mathrm{I}$ concentration) and $64 \%$ in $A$. annua (NAA+Kn+SA at $1.0+2.5+2.5 \mathrm{mg} / \mathrm{I}$ concentration) were observed when compared to $52 \%$ and $51 \%$, respectively in individual supplementation of plant growth regulators. The phytochemical analysis also revealed the presence of maximum phytochemicals in callus extract compared to leaf extracts of $S$. androgynus and $A$. annua there by corroborating with the results of callus induction. The methanol extracts of both callus and leaf extracts of $S$. androgynus and $A$. annua exhibited antibacterial activity against all the test pathogens viz., S. aureus, B. subtilis, S. typhi and E. coli. A maximum inhibition zone of $20 \mathrm{~mm}$ was observed against $S$. typhi in methanol callus extract of $S$. androgynus followed by $18 \mathrm{~mm}$ inhibition zone against $S$. aureus with same extract. It was evident from the results both callus and leaf extracts of the selected plants possessed potential antibacterial activity against all the test pathogens with one or the other solvent extracts. The findings provide a new facelift for callus induction using salicylic acid in selected plants and also pave way for identification of novel compounds for drug development from $S$. androgynus and $A$. annua.
\end{abstract}

Keywords: Antibacterial, Artemisia annua, Callus extract, Phytochemicals, Salicylic acid, Sauropus androgynus

\section{INTRODUCTION}

The past few decades have seen increasing scientific interest in the both growth of plant tissue culture and the commercial development of this technology as means of producing valuable phytochemicals. The accumulation of phytochemicals in the plant cell cultures has been studied for more than thirty years, and the generated knowledge has helped in the realization of using cell cultures for production of desired phytochemicals (Castello et al., 2002). Although very few plant cell processes are operating commercially, the most successful commercial pharmaceuticals produced from undifferentiated cell cultures are anti-biotic compounds (Khafagi et al., 2003). Medicinal components from plants play an important role in conventional as well as Western medicine. Plant extracts and compounds derived from plants are in use as drug from the ancient times. The medicinal value of a plant lies in some chemical substances that produce a definite physiological action on the human body. The most important of these bioactive constituents of plants are alkaloids, tannins and flavonoids (Hussain et al., 2012). The development of drug resistance in human pathogens against commonly used antibiotics has necessitated a search for new antimicrobial substances from other sources including plants (Mahendra et al., 2016).
Many of the plant species has been evaluated for antimicrobial properties but majority of them have not been systematically evaluated and a lot of attention is being derived to evaluate plant extracts as antibacterial agents against resistant plant pathogens (Arumugum et al., 2011). It is important to develop an efficient protocol for callus proliferation in order to start in vitro selection for the development of maximum amount of callus using various explants and media having different composition of growth hormones. Efforts to produce large quantities of active secondary compounds by plant tissue culture techniques have been developed for the rapid, large scale production of cells and their secondary compounds (Lee et al., 2011). Through this approach we can isolate active components through callus without exploiting the plants from natural resources.

Artemisia annua L. and Sauropus androgynus (L.) Merr. are known for their medicinal properties from ancient times. These plants generally grow in tropical and temperate regions of Asia. The genus Artemisia belongs to the family Compositae and the species of Artemisia are astringent, sweet, thermogenic, diuretic, febrifuge, constipating, anthelmintic and are also used in vitiated conditions for kapha, diarrhoea, fever and intestinal worms (Shah, 2013). The plant $S$. androgynus is rich in its nutritive value and is superior to other commonly consumed leafy vegetables in India. It produces high 
nutritious of $6.4 \%$ protein leaves that taste like peas. In Indonesia, the leaves of the plant are used to make a strong rosemary infusion, believed to improve the flow of breast milk for breast feeding mothers. It is a good source of vitamin K (Bunawan et al., 2015). Therefore, the present study has been carried out to induce callus from $A$. annua and $S$. androgynus for the first time using salicylic acid as a growth regulator and also to comparatively evaluate the presence of bioactive compounds and antibacterial activity of in vitro derived callus and in vivo plants.

\section{MATERIALS AND METHODS}

Plant collection: The fresh leaf material was collected from mature plants of $A$. annua and $S$. androgynus which is maintained in the medicinal plant garden of Botany department, University of Mysore.

Induction of callus: Murashige and Skoog (MS) medium supplemented with different concentrations and combinations of growth hormones were used for callus initiation and proliferation (Murashige and Skoog, 1962). MS medium without any plant growth regulators were used as control. The leaves of $A$. annua and $S$. androgynus were cut into required sizes and inoculated on to MS medium fortified with various concentrations of plant growth regulators to initiate the callus. The cultures were incubated under 24 hours dark cycle at $20 \pm 2^{\circ} \mathrm{C}$ initially and transferred to light (16 hours light and 8 hours dark) after one week of dark incubation. Details regarding quantity of callus color, type and number of days to callus formation were observed and results were recorded.

Extract of plant material: The collected leaf material of the selected plants were washed in running tap water and then shade dried to complete dryness and powdered using wearing blender. The mature callus (50day-old) were harvested and dried at $30-40^{\circ} \mathrm{C}$ overnight and powdered. Fifty gram each of plant material was filled in the thimble separately and successively extracted with heaxane, chloroform, ethyl acetate and methanol based on their polarity with the help of Soxhlet extractor. After extraction, each of the collected extract was subjected to flash evaporation and the concentrated extracts were stored at $4^{\circ} \mathrm{C}$ in air tight vials (Harborne, 1973).

Phytochemical analysis: The collected plant extracts were subjected to qualitative phytochemical screening for identification of various classes of active chemical constituents using the methods described by Harborne (1973) and Trease \& Evans (1987).

\section{Evaluation of antibacterial activity}

Test microorganisms: All the extracts of the plant were screened for antibacterial activity against indicator bacteria including both Gram-positive (Staphylococcus aureus MTCC 7443 and Bacillus subtilis MTCC 121) and Gram-negative (Escherichia coli MTCC 7410 and Salmonella typhi MTCC 733) bacteria obtained from
Microbial Type Culture Collection and Gene Bank (MTCC), India and used throughout the study. All the bacterial cultures were adjusted to $0.5 \mathrm{McF}$ arland standards containing approximately $1.5 \times 10^{8} \mathrm{cfu} / \mathrm{ml}$ (Schwalbe et al., 2007).

Antibacterial activity: In vitro antibacterial activity was carried out by agar well diffusion method to determine the inhibitory activity of the tested extracts. The pure cultures of all bacteria were maintained by inoculating $150 \mu \mathrm{L}$ of bacterial suspension on Nutrient Broth (NB) and incubated at $37^{\circ} \mathrm{C}$. Each bacterial strain was then spread uniformly on to the individual plates containing Nutrient agar (NA) media using sterile glass stirrer. A $10 \mathrm{~mm}$ well were made into each Petri plates using sterile cork borer and to the wells about $50 \mu \mathrm{l}$ solution of all the plant extracts (at $25,50,75$ and $100 \mu \mathrm{g} /$ well concentration) were added using sterilized dropping pipettes into the wells and allowed to diffuse at room temperature for 2 hours. Streptomycin and respective solvents served as positive and negative control, respectively. The plates were then incubated at $37^{\circ} \mathrm{C}$ for 24 hours. After incubation, the zone of inhibition was measured in millimeter (Murray et al., 1995). The experiments were carried out in triplicates.

\section{RESULTS AND DISCUSSION}

Induction of callus: In the present study callus induction was observed only on the medium supplemented with growth regulators in both the species and there was no callus formation on hormone free medium. Similar results have been obtained in the cultures of $S$. androgynous where supplementation of growth hormones resulted in the induction of callus rather than hormone free MS medium (Arivalagan et al., 2012). Among the individual growth regulators used, maximum callus induction of $52 \%$ was observed in MS medium supplemented with NAA at $1 \mathrm{mg} / 1$ concentration in $S$. androgynus, whereas $51 \%$ callus induction was observed in A. annua supplemented with 2,4-D at $1.5 \mathrm{mg} / \mathrm{l}$ (Table 1). Many researchers have reported the use of 2,4-D, NAA and BAP for callus induction in various other medicinal plants (Malek et al., 2010; Usman et al., 2011; Thiruvengadam et al., 2012; ALHussaini et al., 2015; Bakhtiar et al., 2016). Further, it was also observed that, when the plant materials were grown on MS medium supplemented with combinations of growth regulators the percent callus induction was higher when compared to individual growth hormones supplementation. The results clearly indicated that, salicylic acid induced maximum callus formation of $72 \%$ in $S$. androgynus when grown on MS medium supplemented with NAA $+\mathrm{BAP}+\mathrm{SA}$ at the concentration of $1+2.5+2.5 \mathrm{mg} / 1$, while in $A$. annua maximum induction of callus of $64 \%$ was observed in media supplemented with $\mathrm{NAA}+\mathrm{Kn}+\mathrm{SA}$ at $1.0+2.5+2.5 \mathrm{mg} / 1$ (Table 2). This is the first report on the use of salicylic 
Manasa Govindaraju et al. / J. Appl. \& Nat. Sci. 8 (4): 2189-2195 (2016)

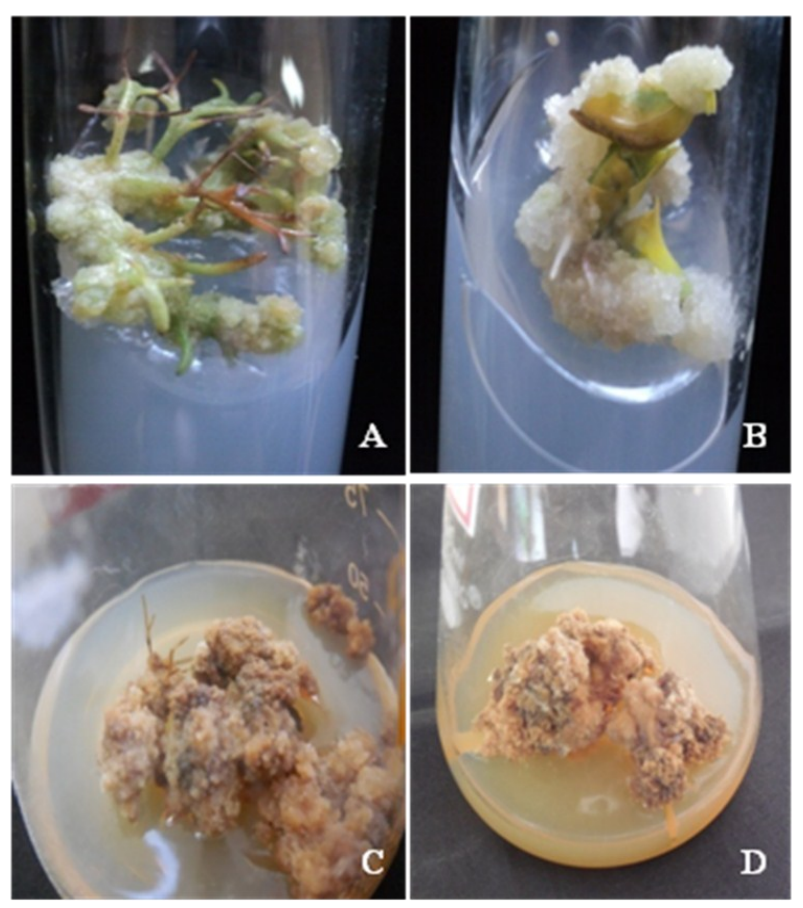

Fig. 1. Leaf callus initiation of selected plants. A- A. annua; $B$-S. androgynus; $C$ - Proliferated callus of A. annua; $D$ Proliferated callus of S. androgynus.

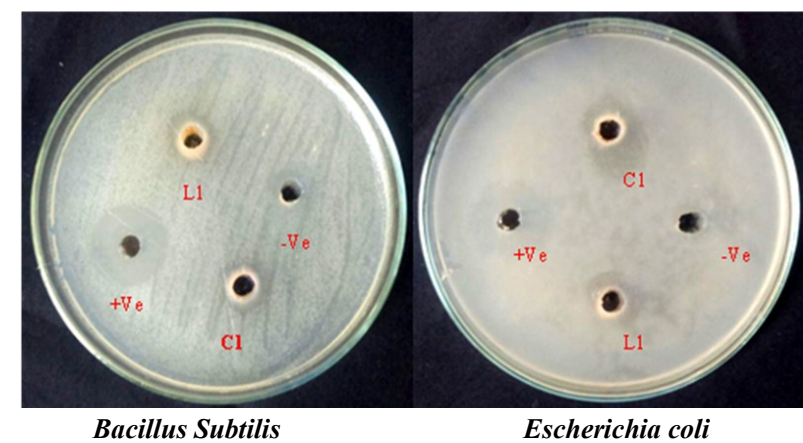

Bacillus Subtilis

Escherichia coli

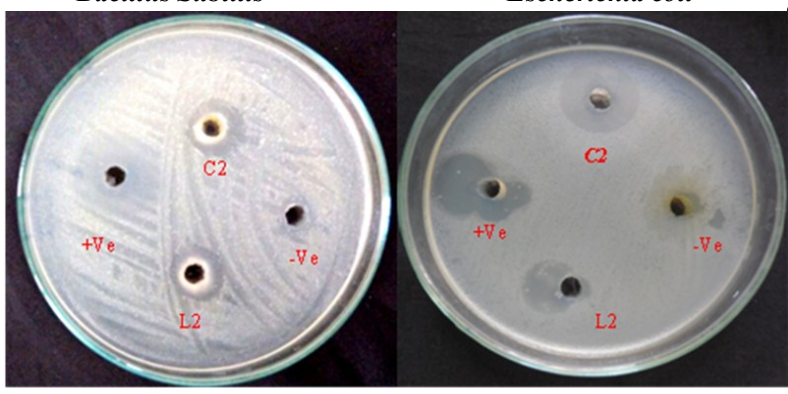

Staphylococcus aureus

Salmonella typhi

Fig. 2. Antibacterial activity of A. annua and S. androgynus. C1: Methanol callus extract of A. annua; C2: Methanol callus extract of $S$. androgynus; L1: Methanol leaf extract of $A$. annua; L2: Methanol leaf extract of S. androgynus.

Table 1. Effect of supplementation of growth regulators to MS medium for callus induction of A. annua and S. androgynus at different concentrations.

\begin{tabular}{|c|c|c|c|c|c|}
\hline $\begin{array}{l}\text { Name of } \\
\text { the media }\end{array}$ & $\begin{array}{l}\text { Type of } \\
\text { PGR }\end{array}$ & $\begin{array}{c}\text { Concentration } \\
\text { in } \mathrm{mg} / \mathrm{l}\end{array}$ & $\begin{array}{l}\text { Callus re- } \\
\text { sponse }\end{array}$ & \% Response & $\begin{array}{c}\% \text { of forming } \\
\text { callus }\end{array}$ \\
\hline \multicolumn{6}{|c|}{ A. annua } \\
\hline \multirow{13}{*}{ MS } & Basal medium & - & - & - & - \\
\hline & & 0.5 & - & - & - \\
\hline & BAP & 1.0 & + & 30 & $5.21 \pm 0.71$ \\
\hline & & 1.5 & ++ & 44 & $7.40 \pm 0.41$ \\
\hline & & 0.5 & - & - & - \\
\hline & NAA & 1.0 & - & - & - \\
\hline & & 1.5 & + & 32 & $5.45 \pm 0.49$ \\
\hline & & 0.5 & + & 31 & $4.49 \pm 0.34$ \\
\hline & 2,4-D & 1.0 & ++ & 40 & $8.50 \pm 0.52$ \\
\hline & & 1.5 & ++ & 51 & $9.45 \pm 0.42$ \\
\hline & & 0.5 & + & 10 & $2.12 \pm 0.36$ \\
\hline & $\mathbf{S A}$ & 1.0 & _- & - & - \\
\hline & & 1.5 & & - & - \\
\hline \multicolumn{6}{|c|}{ S. androgynus } \\
\hline \multirow{14}{*}{ MS } & Basal medium & - & - & - & - \\
\hline & & 0.5 & + & 29 & $4.25 \pm 0.52$ \\
\hline & BAP & 1.0 & ++ & 35 & $5.49 \pm 0.56$ \\
\hline & & 1.5 & ++ & 38 & $5.90 \pm 0.58$ \\
\hline & & 0.5 & + & 44 & $6.55 \pm 0.54$ \\
\hline & NAA & 1.0 & ++ & 50 & $6.55 \pm 0.52$ \\
\hline & & 1.5 & ++ & 52 & $7.54 \pm 0.46$ \\
\hline & & & & & \\
\hline & & 0.5 & - & - & - \\
\hline & $2,4-\mathrm{D}$ & 1.0 & + & 40 & $6.12 \pm 0.62$ \\
\hline & & 1.5 & ++ & 45 & $5.59 \pm 0.56$ \\
\hline & & 0.5 & + & 13 & $2.02 \pm 0.42$ \\
\hline & SA & 1.0 & - & - & - \\
\hline & & 1.5 & - & - & - \\
\hline
\end{tabular}


Table 2. Effect of supplementation of growth regulators in combination to MS medium for callus induction of $A$. annua and $S$. androgynus at different concentrations.

\begin{tabular}{|c|c|c|c|c|c|}
\hline $\begin{array}{l}\text { Name of } \\
\text { the media }\end{array}$ & Combination of PGR & $\begin{array}{c}\text { Concentration } \\
\text { in } \mathrm{mg} / \mathrm{l} \\
\end{array}$ & Callus response & \% Response & $\begin{array}{c}\% \text { of forming cal- } \\
\text { lus }\end{array}$ \\
\hline \multicolumn{6}{|c|}{ A. annua } \\
\hline \multirow{21}{*}{ MS } & Basal & - & - & - & - \\
\hline & \multirow{3}{*}{$\mathrm{NAA}+\mathrm{BAP}+\mathrm{SA}$} & $0.5+0.5+0.5$ & - & - & - \\
\hline & & $0.5+1.0+1.0$ & + & 36 & $6.39 \pm 0.45$ \\
\hline & & $1.0+1.5+1.5$ & ++ & 48 & $7.20 \pm 0.56$ \\
\hline & \multirow{7}{*}{$\mathrm{NAA}+\mathrm{Kn}+\mathrm{SA}$} & $1.0+2.0+2.0$ & +++ & 52 & $8.54 \pm 0.84$ \\
\hline & & $1.0+2.5+2.5$ & ++t & 64 & $8.91 \pm 0.41$ \\
\hline & & $0.5+0.5+0.5$ & + & - & - \\
\hline & & $0.5+1.0+1.0$ & ++ & 29 & $4.63 \pm 0.25$ \\
\hline & & $1.0+1.5+1.5$ & ++ & 34 & $6.39 \pm 0.87$ \\
\hline & & $1.0+2.0+2.0$ & ++ & 47 & $7.52 \pm 0.71$ \\
\hline & & $1.0+2.5+2.5$ & +++ & 64 & $9.84 \pm 0.31$ \\
\hline & \multirow{3}{*}{$2,4 \mathrm{D}+\mathrm{BAP}+\mathrm{SA}$} & $0.5+0.5+0.5$ & - & 34 & $5.54 \pm 0.52$ \\
\hline & & $0.5+1.0+1.0$ & + & 42 & $6 . .92 \pm 0.85$ \\
\hline & & $1.0+1.5+1.5$ & ++ & 48 & $7.20 \pm 0.80$ \\
\hline & \multirow{7}{*}{$2,4 \mathrm{D}+\mathrm{Kn}+\mathrm{SA}$} & $1.0+2.0+2.0$ & ++ & 56 & $8.44 \pm 0.64$ \\
\hline & & $1.0+2.5+2.5$ & +++ & 62 & $9.10 \pm 0.21$ \\
\hline & & $0.5+0.5+0.5$ & - & - & - \\
\hline & & $0.5+1.0+1.0$ & - & - & - \\
\hline & & $1.0+1.5+1.5$ & + & 32 & $5.54 \pm 0.32$ \\
\hline & & $1.0+2.0+2.0$ & + & 38 & $6.36 \pm 0.44$ \\
\hline & & $1.0+2.5+2.5$ & ++ & 48 & $7.19 \pm 0.87$ \\
\hline \multicolumn{6}{|c|}{ S. androgynus } \\
\hline \multirow{20}{*}{ MS } & \multirow{3}{*}{$\mathrm{NAA}+\mathrm{BAP}+\mathrm{SA}$} & $0.5+0.5+0.5$ & + & 32 & $4.26 \pm 0.54$ \\
\hline & & $0.5+1.0+1.0$ & ++ & 38 & $5.21 \pm 0.62$ \\
\hline & & $1.0+1.5+1.5$ & ++ & 46 & $6.42 \pm 0.42$ \\
\hline & \multirow{7}{*}{$\mathrm{NAA}+\mathrm{Kn}+\mathrm{SA}$} & $1.0+2.0+2.0$ & +++ & 54 & $7.32 \pm 0.54$ \\
\hline & & $1.0+2.5+2.5$ & ++++ & 72 & $9.20 \pm 0.24$ \\
\hline & & $0.5+0.5+0.5$ & + & 42 & $5.10- \pm 0.42$ \\
\hline & & $0.5+1.0+1.0$ & ++ & 54 & $6.20 \pm 0.54$ \\
\hline & & $1.0+1.5+1.5$ & ++ & 58 & $7.20 \pm 0.62$ \\
\hline & & $1.0+2.0+2.0$ & +++ & 62 & $8.10 \pm 0.22$ \\
\hline & & $1.0+2.5+2.5$ & +++ & 68 & $8.92 \pm 0.44$ \\
\hline & \multirow{3}{*}{$2,4 \mathrm{D}+\mathrm{BAP}+\mathrm{SA}$} & $0.5+0.5+0.5$ & - & 40 & $6.20 \pm 0.42$ \\
\hline & & $0.5+1.0+1.0$ & + & 52 & $7.12 \pm 0.54$ \\
\hline & & $1.0+1.5+1.5$ & ++ & 56 & $7.54 \pm 0.44$ \\
\hline & \multirow{7}{*}{$2,4-\mathrm{D}+\mathrm{Kn}+\mathrm{SA}$} & $1.0+2.0+2.0$ & ++ & 61 & $8.20 \pm 0.62$ \\
\hline & & $1.0+2.5+2.5$ & +++ & 64 & $8.68 \pm 0.22$ \\
\hline & & $0.5+0.5+0.5$ & - & - & - \\
\hline & & $0.5+1.0+1.0$ & - & - & - \\
\hline & & $1.0+1.5+1.5$ & - & - & - \\
\hline & & $1.0+2.0+2.0$ & + & 42 & $6.80 \pm 0.64$ \\
\hline & & $1.0+2.5+2.5$ & ++ & 54 & $7.54 \pm 0.44$ \\
\hline
\end{tabular}

acid as a growth regulator for callus induction (Fig. 1). Morphologically the callus in both the species is slightly brown, friable and embryogenic in most of the replicates and in some replicates it was yellow, soft, juicy and non-embryogenic.

Phytochemical analysis: Phytochemical analysis of leaf and callus extracts of selected plants is depicted in Table 3. The extracts of both in vitro and in vivo plant materials showed the presence of sterols, triterpene, saponins, alkaloids, tannins, flavonoids, carbohydrates, resins, proteins and glycosides. Maximum phytochemicals were found in the chloroform extracts of both in vitro and in vivo of $A$. annua, while maximum phytochemicals were observed in methanolic leaf extract of $S$. androgynus but in case of callus it contained only carbohydrates and resins. Similarly, it was also noted that, maximum phytochemical constituents were observed in callus extract when compared to leaf extracts

$\begin{array}{ccccr}\text { in } & \text { Tecoma atans and } & \text { A. } & \text { sieversiana } \\ \text { ( } & \text { Prathyusha } & \text { et } & \text { al., } & 2010 \text {; }\end{array}$

Namde and Wani, 2014). Among the secondary metabolites detected in plant and callus extracts, flavonoids are known for excellent free radical scavenging properties (Annegowda et al., 2010; Mahendra et al., 2016), alkaloids and tannins for pharmacological activities (Cragg and Newman, 2005) and phenols, saponins, alkaloids and flavonoids for their antibacterial potentials (Akharaiyi et al., 2012).

Antibacterial activity: The methanol extracts of both callus and leaf extracts of selected plants showed significant antibacterial activity against test pathogens when compared other solvent extracts. The results are in accordance with the findings of Naz et al. (2015) wherein Catharanthus roseus methanol extracts had maximum inhibition to test pathogens when compared to other solvent extracts. Among the selected plants, $S$. 


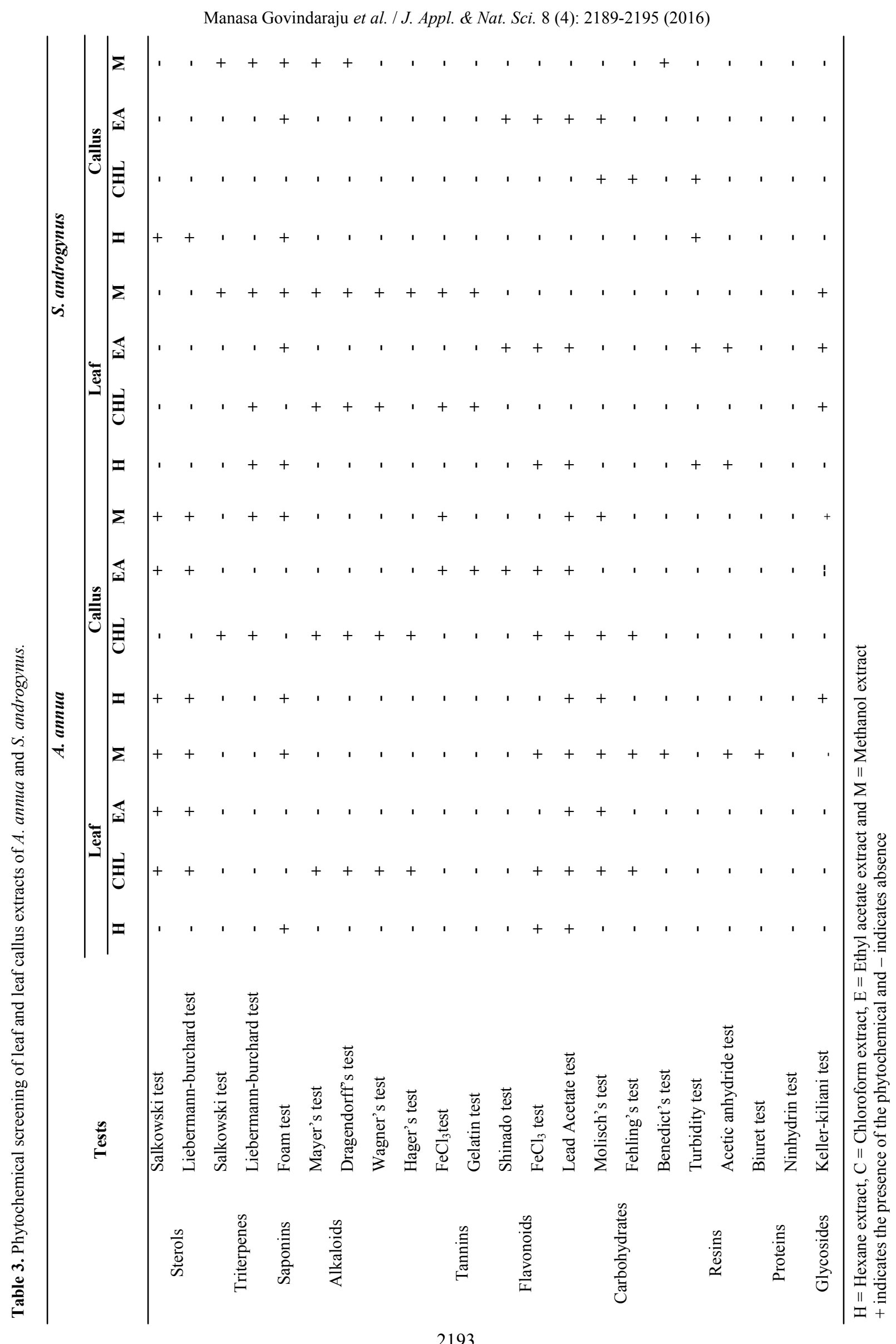




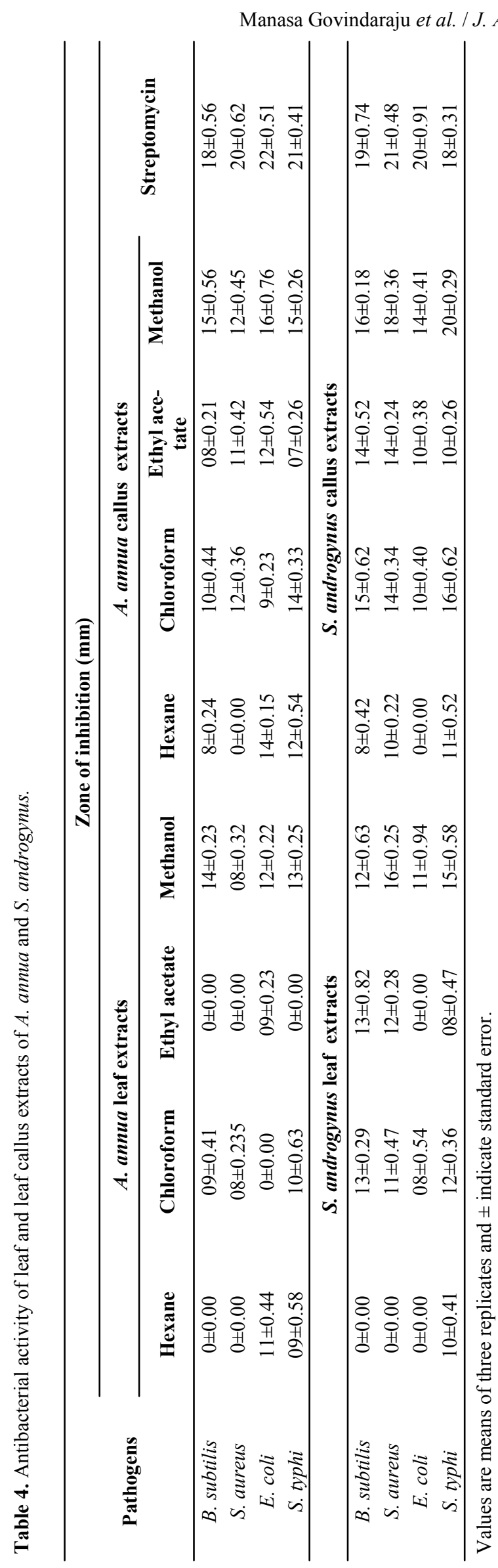

androgynus callus extracts offered maximum inhibition zone of 16, 18, 14 and $20 \mathrm{~mm}$ when compared to leaf extracts 12, 16, 11 and $15 \mathrm{~mm}$ against $B$. subtilis, $S$. aureus, E. coli and S. typhi, respectively (Table 4). Whereas the callus extracts of $A$. annua offered a maximum of 15, 12, 16 and $15 \mathrm{~mm}$ zone of inhibition against $B$. subtilis, $S$. aureus, E. coli and $S$. typhi, respectively (Fig. 2). The results corroborates with the findings of Nagarjan et al. (2009), where they have reported that, callus extracts show maximum inhibition for bacterial pathogen when compared to natural leaf extracts. The higher antibacterial activity in callus extract is due to the addition of sufficient micro and macro-nutrients for induction of callus which in turn results in profuse growth of callus their by inducing the maximum accumulation of secondary metabolites (Chakraborty et al., 2013).

\section{Conclusion}

The present study highlights the use of salicylic acid as plant growth regulator for the first time for the induction of callus through tissue culture. The results for callus induction in $S$. androgynus and A. annua were higher in salicylic acid amended MS medium when compared with individual plant growth regulators. Further, the study clearly indicated the presence of maximum phytochemical constituents in callus extract when compared to leaf extracts. It was also clear from the studies that, the plant posses potential antibacterial activity both in callus and leaf extracts, while higher activity was noted in callus extracts which may be due favorable condition provided for callus induction resulting in profuse growth of callus which influence the immense accumulation of secondary metabolites.

\section{ACKNOWLEDGEMENTS}

The authors are thankful to University of Mysore, Mysore for providing laboratory facility in Department of Studies in Botany for completing this research work.

\section{REFERENCES}

Akharaiyi, F.C., Boboye, B. and Adetuyi, F.C. (2012). Antibacterial, phytochemical and antioxidant activities of the leaf extracts of Gliricidia sepium and Spathodea campanulata. World App. Sci. J., 16(4): 523-530

AL-Hussaini, Z.A., Yousif, S.H. and AL-Ajeely, S.A. (2015). Effect of different medium on callus induction and regeneration in potato cultivars. Int. J. Curr. Microbiol. App. Sci., 4(5): 856-865

Annegowda, H.V., Nee, C.W., Mordi, M.N., Ramanathan, S. and Mansor, S.M. (2010). Hydrolysed extracts of Terminalia catappa L. leaf. Asian J. Plant Sci., 9(8): 479485

Arivalagan, U., Alderson, P.G. and Nagarajan, A. (2012). Effect of growth hormones on callus induction of Sauropus androgynous (sweet shoot). Annals of Biol. Res., 3(10): 4668-4674

Arumugam, T., Ayyanar, M., Justin, Y., and Pillai, K. 
(2011). Phytochemical screening and antibacterial activity of leaf and callus extracts of Centella asiatica. Bang. J. Pharmacol., 6(1): 55-60

Bakhtiar, Z., Mirjalili, M.H. and Sonboli, A. (2016). In vitro callus induction and micropropagation of Thymus persicus (Lamiaceae), an endangered medicinal plant. Crop. Breed. Appl. Biotechnol., 16: 48-54

Bunawan, H., Baharum, S.N. and Noor, N.M. (2015). Sauropus androgynus (L.) Merr. Induced Bronchiolitis obliterans: From Botanical Studies to Toxicology. Evid. Based Complement. Alternat. Med., 1(1): 1-7

Castello, M.C., Phatak, A., Chandra, N. and Sharon, M. (2002). Antimicrobial activity of crude extracts from plant parts and corresponding calli of Bixa orellana L. Indian J. Exp. Biol., 40: 1378-1381

Chakraborty, N. and Banerjee, D. (2013). Influence of plant growth regulators on callus mediated regeneration and secondary metabolites synthesis in Withania somnifera L. Dunal. Physiol. Mol. Biol. Plants., 19(3): 117-125

Cragg, G.M. and Newman, D.J. (2005). Biodiversity: A continuing source of novel drug leads. Pure Appl. Chem., 77(1): 7-24

Harborne, J.B. (1973). Phytochemical methods. Chapman and hall Ltd., London: U.K.

Hussain, Md. S., Fareed, S., Ansari, S., Rahman, Md. S., Ahmad, I.Z. and Saeed, M. (2012). Current approaches toward production of secondary plant metabolites. $J$. Pharm. Bioallied. Sci., 4(1): 10-20

Khafagi, I., Dewedar, A. and Amein, M. (2003). Opportunities of finding novel anti-infective agents from plant cell cultures. Curr. Med. Chem. Anti-Infect. Agent., 2: 2191211

Lee, Y., Lee, D., Lee, H., Kim, S., Lee, W., Kim, S. and Kim, M. (2011). Influence of auxins, cytokinins, and nitrogen on production of rutin from callus and adventitious roots of the white mulberry tree (Morus alba L.). Plant. Cell. Tiss. Organ. Cult., 105(1): 9-19

Mahendra, C., Manasa, G., Murali, M., Amruthesh, K.N., Sudarshana, M.S. and Lingaraju, D.P. (2016). Antibacterial and antioxidant properties of Argyreia osyrensis Roth. Ann. of Phytomed., 5(1): 110-115
Malek, M.A., Mannan, M.A., Khanam, D., Molla, M.H. and Kathun, M. (2010). In vitro regeneration through callus in pointed Gourd (Trichosanthes dioica Roxb.) Bangladesh. J. Agric. Res., 35(3): 465-473

Murashige, T. and Skoog, F. (1962). A revised medium for rapid growth and bioassays with tobacco tissue cultures. Plant Physiol., 150: 473-497

Murray, P.R, Baron, E.J, Pfaller, M.A, Tenover, F.C. and Yolken, H.R. (1995). Manual of clinical microbiology. $6^{\text {th }}$ Ed. ASM Press, Washington DC.

Nagarajan, S.M. (2009). Comparative antimicrobial activity of callus and natural plant extracts of Solanum trilobatum L. Ancie. Sci. of Life, 28(3): 3-5

Namde, H. and Wani, M. (2014). Callus induction studies and active components and antioxidant activity investigation from leaves and callus of Tecoma stans L. Juss. Ex. Kunth. Res. J. of Pharm. Biol. and Che. Sci., 5(2): 604-610

Naz, S., Haq, R., Aslam, F. and Ilyas, S. (2015). Evaluation of antimicrobial activity of extracts of in vivo and in vitro grown Vinca rosea L. (Catharanthus roseus) against pathogens. Pak. J. Pharm. Sci., 28(3): 849-853

Prathyusha, P., Subramanian, M.S. Nisha, M.C., Santhanakrishnan, R. and Seena, M.S. (2010). Phytochemical screening of aerial parts of Artemisia parviflora Roxb. J. Med. Plants, 2(2): 137-140

Schwalbe, R., Moore, L.S. and Goodwin, A.C. (2007). Antimicrobial susceptibility testing protocols. CRC Press, Taylor and Francis Group, Boca Raton, London, New York.

Shah, N.C. ( 2013). The Economic and Medicinal Artemisia species in India. J. Sci. Technol., 1(1): 29-38

Thiruvengadam, M., Praveen, N. and Chung, I. (2012). In vitro regeneration from internodal explants of bitter melon (Momordica charantia L.) via indirect organogenesis. Afr. J. Biotechnol., 11(33): 8218-8224

Trease, G.E. and Evans, W.C. (1987). A text book of Pharmacognosy. Tindal, Oxford: ELSB/ Bailliere.

Usman, M., Hussain, Z. and Fatima, B. (2011). Somatic embryogenesis and shoot regeneration induced in $\mathrm{Cu}$ - 